\title{
STUDIES ON HEMOGLOBIN METABOLISM. II. PATHWAYS OF HEMOGLOBIN IRON METABOLISM IN NORMAL MAN *
}

\author{
By LARS GARBY † AND WARD D. NOYES $\ddagger$ \\ (From the Department of Medicine, School of Medicine, University of Washington, \\ Seattle, Wash.)
}

(Submitted for publication February 9, 1959; accepted May 7, 1959)

It has been suggested by earlier work $(1,2)$ and especially by a recent paper by Finch (3), that when isotopically labeled iron is administered to the body the time required for complete isotopic equilibrium to be reached is very long, a matter of years. It is well established that labeled iron bound to transferrin is found almost entirely in the red cells two to three weeks after injection. These findings could well be explained on the basis of poor exchangeability of the storage iron, since lattice-bound atoms of such a semicrystalline structure $(4,5)$ are in general very firmly bound. An alternative explanation is that storage iron is largely bypassed in the normal endogenous cycling of iron. First, it is quite possible that at least part of the products of red cell degradation are specifically taken up by cells of the bone marrow such as reticuloendothelial cells and red cell precursors (6), and in this manner exclude major participation by storage iron in heme formation. Second, the red cell iron compartment has the properties of a large nonexchangeable pool interposed between two one-way flows with a relatively fixed time (about 120 days) spent by the isotope in the pool. For this reason alone isotopic equilibrium within the body will take a very long time.

The present investigation was undertaken to define more exactly the pathways of iron following the degradation of hemoglobin when this was administered intravenously in amounts comparable to physiological loads. In normal man, the total hemoglobin turnover is about 6 to $7 \mathrm{Gm}$. per day or about $270 \mathrm{mg}$. per hour. The present data

* This investigation was supported by Research Grant No. H-2994 from the United States Public Health Service.

$\dagger$ In receipt of a traveling grant from the Swedish Medical Research Council. Present address: Swedish Medical Research Council Unit for Pediatric Hematology, University Hospital, Uppsala, Sweden.

$\$$ United States Public Health Research Fellow of the National Heart Institute, National Institutes of Health, Bethesda, Md. were obtained after injection of 100 to $250 \mathrm{mg}$. of hemoglobin. The reappearance of the labeled iron in plasma, presumably as transferrin iron, and the subsequent incorporation of this iron into circulating red cells was studied.

\section{MATERIALS AND METHODS}

In a previous paper (7) the preparation of an $\mathrm{Fe}^{50}$ tagged hemoglobin solution and its intravenous injection in 12 healthy, adult, volunteer subjects was described. The present data are based upon further observations on these subjects and one additional subject. The time course of the radioactivity of the nonhemoglobin, easily hydrolyzable iron in the plasma was followed. The time course of the radioactivity of the red cells was also followed. The wet-ashing and counting procedures were identical to those described in a previous paper (7). Hematocrits were determined according to Wintrobe (8). Estimations of the red cell volume and the plasma volume were made using a value of $29 \mathrm{ml}$. per $\mathrm{Kg}$. body weight for red cell volume and a body hematocrit of 0.92 times the venous hematocrit. The systematic error introduced by such a calculation is unlikely to exceed 10 per cent for the red cell volume and 20 per cent for the plasma volume, and probably does not exceed 5 and 10 per cent, respectively (9).

\section{RESULTS}

The time course of the radioactivity in the nonhemoglobin, easily hydrolyzable iron in the plasma after injection of labeled hemoglobin is shown in Figure 1. The hemoglobin injection was made at zero time and the amount of hemoglobin injected was $1.3 \mathrm{mg}$. per $\mathrm{Kg}$. body weight in 10 subjects and $3.5 \mathrm{mg}$. per $\mathrm{Kg}$. body weight in three subjects [compare with previous paper (7)]. No significant difference was found in the curves of the different loads. The interrupted line represents the fraction of the injected dose which was split off from hemoglobin and transported into the plasma. This curve was obtained from the continuous line by adding graphically the cumulative amounts which left the plasma each 
time. The procedure utilized the fact that the disappearance of about 90 per cent of labeled transferrin iron from the plasma can be described adequately by a single exponential with the coefficient of transfer of 0.45 per hour $(10,11)$ and a standard error of 0.04 per hour.

The time course of the radioactivity from $\mathrm{Fe}^{59}$ in circulating red cells is shown in Figure 2. Not included in this figure are 10 additional values obtained between 54 and 69 days after the injection, from which a mean value of 107 per cent (S.E. $=7$ per cent $)$ was calculated.

\section{DISCUSSION}

The time course of the appearance of the labeled iron in plasma after injection of hemoglobin showed that about 30 per cent of the injected activity was released and passed into the plasma after about two hours; another 10 per cent was passed during the next six hours. It is thus evident that plasma hemoglobin rapidly enters the catabolic cycle. This type of appearance curve suggested that considerably more iron was released from heme than passed through the plasma. Two possibilities are suggested concerning the fate of the iron which did not pass into the plasma during the time of investigation. The first possibility is that part of the iron was incorporated into slowly turned-over storage compounds in reticuloendothelial cells not located in the bone marrow. The second possibility is that part of the hemoglobin catabolism took place in the bone marrow and that subsequent liberation of iron to

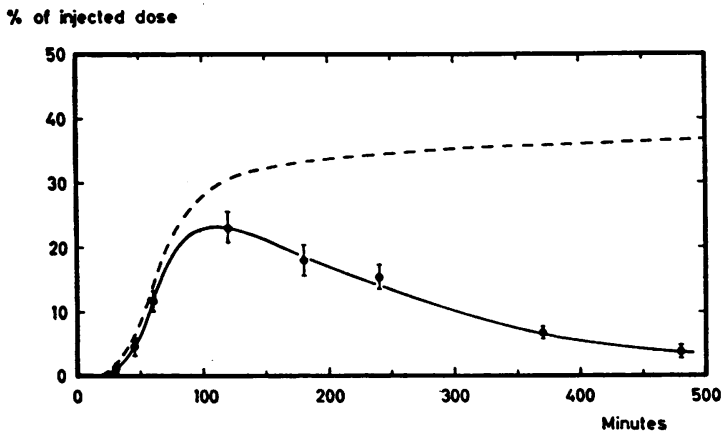

Fig. 1. The Time Course of the Radioactivity $\left(\mathrm{Fe}^{\text {60 }}\right.$ ) in the Nonhemoglobin Iron in the Plasma After Injection of Labeled Hemoglobin at Zero TIME

Mean values \pm S.E. in 13 experiments.

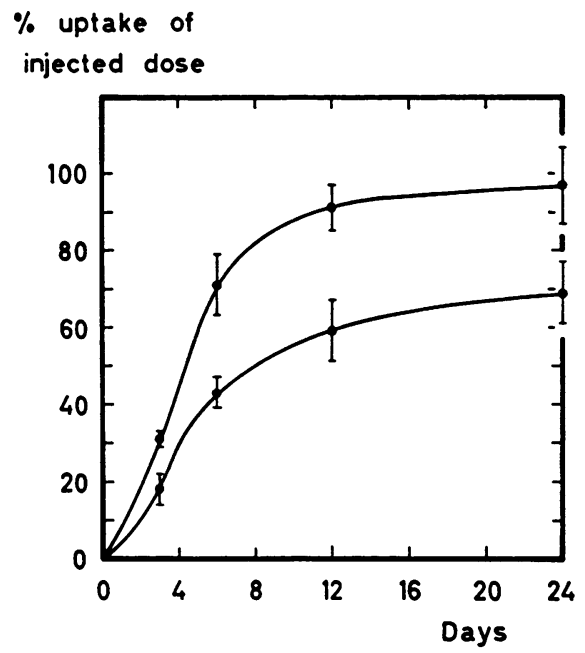

Fig. 2. The Time Course of the Radionctivity $\left(\mathrm{FE}^{59}\right)$ in Circulating Red Cells After Injection of Labeled Hemoglobin at Zero Time

Mean values \pm S.E. in 13 experiments. The upper curve represents values (mean \pm 2 S.E.) from injection of labeled transferrin (3).

the red cell precursors bypassed the plasma. The present data offer no choice between the two possibilities. It is, however, of interest that Mann, Sheard, Bollman and Baldes $(12,13)$ were able to show higher concentrations of bilirubin in venous blood from the marrow than in arterial blood and that they concluded the bone marrow was an important site of hemoglobin breakdown.

The time course of the uptake of labeled iron into circulating red cells showed a smaller proportion of the injected activity in the red cells at any time than after injection of transferrin-bound iron. This is in accordance with the idea that at least part of the iron from hemoglobin is incorporated into relatively inaccessible iron compounds. The turnover of this pool, however, was sufficiently rapid to allow most of the injected hemoglobin iron to be reutilized within two months after injection.

It has been shown that in various types of hemolytic disorders, the rate of uptake of radioiron in the circulating red cells after intravenous injection of $\mathrm{Fe}^{59}$ bound to plasma transferrin and the subsequently reached plateau is lower than in normals $(10,14-16)$. This may be interpreted as the result of the very early destruction of young red cells and the degradation of their hemoglobin in the reticuloendothelial system and/or increased 
intravascular hemolysis with resultant shunting of radioactivity into stores. The delay in release of this radioactivity combined with continual loss from the red cell pool might be expected to produce the iron utilization curves which have been described. The present data confirm the participation of such storage iron pools in the distribution of iron from hemoglobin degradation and support the feasibility of this interpretation.

\section{SUMMARY}

1. The time course of the appearance and disappearance of plasma iron radioactivity after injection of small amounts of labeled hemoglobin has been followed. Also, the time course of the appearance of the labeled iron in red cells was investigated.

2. The data show that hemoglobin, injected in amounts of 100 to $250 \mathrm{mg}$., rapidly enters its catabolic cycle and that at least 40 per cent of the iron is split off within the first few hours after injection. A considerable part of the iron is retained extravascularly for many hours. The subsequent incorporation of the labeled iron into circulating red cells is slower than after administration of transferrin-bound radioiron.

3. The data substantiate the idea that the decreased rate of appearance of radioiron in circulating red cells in certain types of hemolytic anemia may be due to destruction of young cells or increased intravascular hemolysis and subsequent shunting of radioiron into slowly turned-over iron stores.

\section{ACKNOWLEDGMENTS}

We would like to thank Dr. Clement A. Finch for advice and criticism and also Miss Betty Loden for technical assistance.

\section{REFERENCES}

1. Cruz, W. O., Hahn, P. F., and Bale, W. F. Hemoglobin radioactive iron liberated by erythrocyte destruction (acetylphenylhydrazine) promptly reutilized to form new hemoglobin. Amer. J. Physiol. 1942, 135, 595.

2. Gibson, J. G., 2nd, Aub, J. C., Evans, R. D., Peacock, W. C., Irvine, J. W., Jr., and Sack, T. The measurement of post-transfusion survival of pre- served stored human erythrocytes by means of two isotopes of radioactive iron. J. clin. Invest. 1947, 26, 704.

3. Finch, C. A. Body iron exchange in man. J. clin. Invest. 1959, 38, 392.

4. Richter, G. W. A study of hemosiderosis with the aid of electron microscopy. With observations on the relationship between hemosiderin and ferritin. J. exp. Med. 1957, 106, 203.

5. Richter, G. W. Electron microscopy of hemosiderin : Presence of ferritin and occurrence of crystalline lattices in hemosiderin depots. J. biophys. biochem. Cytol. 1958, 4, 55.

6. Bessis, M. C., and Breton-Gorius, J. Iron particles in normal erythroblasts and normal and pathological erythrocytes. J. biophys. biochem. Cytol. 1957, 3, 503.

7. Garby, L., and Noyes, W. Studies on hemoglobin metabolism. I. The kinetic properties of the plasma hemoglobin pool in normal man. J. clin. Invest. 1959, 38, 1479.

8. Wintrobe, M. M. Clinical Hematology, 4th ed. Philadelphia, Lea and Febiger, 1956.

9. Mollison, P. L. Blood transfusion in clinical medicine, 2nd ed. Springfield, Charles C Thomas, 1956.

10. Bothwell, T. H., Hurtado, A. V., Donohue, D. M., and Finch, C. A. Erythrokinetics. IV. The plasma iron turnover as a measure of erythropoiesis. Blood 1957, 12, 409.

11. Giblett, E. R., Coleman, D. H., Pirzio-Biroli, G., Donohue, D. M., Motulsky, A. G., and Finch, C. A. Erythrokinetics: Quantitative measurements of red cell production and destruction in normal subjects and patients with anemia. Blood 1956, 11, 291.

12. Mann, F. C., Sheard, C., Bollman, J. L., and Baldes, E. J. The site of the formation of bilirubin. Amer. J. Physiol. 1925, 74, 497.

13. Mann, F. C., Sheard, C., Bollman, J. L., and Baldes, E. J. The formation of bile pigment from hemoglobin. Amer. J. Physiol. 1926, 76, 306.

14. Huff, R. L., Hennessy, T. G., Austin, R. E., Garcia, J. F., Roberts, B. M., and Lawrence, J. H. Plasma and red cell iron turnover in normal subjects and in patients having various hematopoietic disorders. J. clin. Invest. 1950, 29, 1041.

15. Huff, R. L., Elmlinger, P. J., Garcia, J. F., Oda, J. M., Cockrell, M. C., and Lawrence, J. H. Ferrokinetics in normal persons and in patients having various erythropoietic disorders. J. clin. Invest. 1951, 30, 1512.

16. Elmlinger, P. J., Huff, R. L., Tobias, C. A., and Lawrence, J. H. Iron turnover abnormalities in patients having anemia: Serial blood and in vivo tissue studies with Fe-59. Acta haemat. (Basel) 1953, 9, 73. 